\title{
Two New Records of Odonata in White Nile State, Sudan
}

\author{
Esra Abdelrazig Elfaki ${ }^{1}$ and Tigani Allam ${ }^{2}$ \\ 1. Department of Biodiversity, Environment and Natural Resources and Desertification Research Institute, Khartoum 12217, Sudan \\ 2. Department of Zoology, Faculty of Science, University of Khartoum, Khartoum 11115, Sudan
}

\begin{abstract}
White Nile state characterizes by rich healthy habitats especially wetlands which it supports the diversity of wildlife, Odonata species are actually poorly known in the White Nile region. A systematic survey was carried out in aquatic systems located at six localities: Kosti, Al-Kawwa, ELJebelein, Kenana cities, Om Elganateer and El Shawat islands. A total of 357 belonged to 16 species distributed in 4 families were recorded and observed. Family Libellulidae was dominant, with 9 species, followed by Coenagrionidae, Brachythemis leucosticte showed the highest abundance in compare with other species. ELJebelein area showed highest number of Odonata, while Kenana showed highest diversity, 11 species recorded from Kenana sugar scheme and Kenana Zoo Park, phyllomacromia Africana and Olpogastra lugubris recorded only in Kenana. Agriocnemis exilis and Ictinogomphus ferox were recorded for first time in Sudan.
\end{abstract}

Key words: Odonata, dragonflies, damselflies, Sudan, White Nile.

\section{Introduction}

White Nile state is characterized by its strategic location in central Sudan, it is bordered by Khartoum State in the north, North Kordofan State in the west, South Kodofan State and the Upper Nile State in the southeastern and Al-Gazira \& Sinnar States in the east (Plate 1). The state area is 39,701 square kilometers and the climate of the state characterized by hot, humid rainy summers and warm dry in winter. The geological formation of the state consists of six areas which are: Plains region of the natural and flat with an estimated area of 3,643,119 acres which is equivalent to about $33 \%$ of the area of the state and land area of sedimentary clay and sand area and the Nile Valley area is estimated to about $10 \%$ of the area of the state, also Sub-Saharan sand are sandy area and Rocky hills area is estimated to 94,526 acres which is equivalent to about $1 \%$ of the area of the state. The most important crops are Durra, sesame, groundnuts, millet and wheat and animal resources are 7,875,673 heads. And the most important towns are Kosti, Al-Dweim, Al-Kawwa and Rabak which is the capital of the State,

Corresponding auther: Esra A. Elfaki, master, research field: biodiversity.
Kosti one of the biggest city in White Nile is located on the west site of the White Nile and occupies an important strategic position in central Sudan and going through three lines of communication between different parts of Sudan, namely rail, road and Nile navigation, and gained further interest to focus around the sugar industry. It factories Kenana, Assalaya and White Nile has flourished residential, commercial and have started to attract people from all parts of Sudan. Rabak is second city, located on the east site of the White Nile. White Nile state also characterizes by rich healthy habitats support the diversity of wildlife [1].

Odonata are receiving increasing attention from the public, conservationists and scientists on regional and global levels [2]. Because of their attractive appearance, they can function as guardians of the watershed, being the quintessence of freshwater health. The Odonatafunus of Sudan have been focused on two old papers by Ris, F. [3] on the Nile valley Odonata, and by Happold, D. C. D. [4] how studied Odonata on Khartoum and also Jebel Marra area. There is a contribution by El Rayah, E. A. et al. [5], Dumont, H. J. and Martens, K. [6] who studied the ecology of some species that occur near Khartoum. And also 


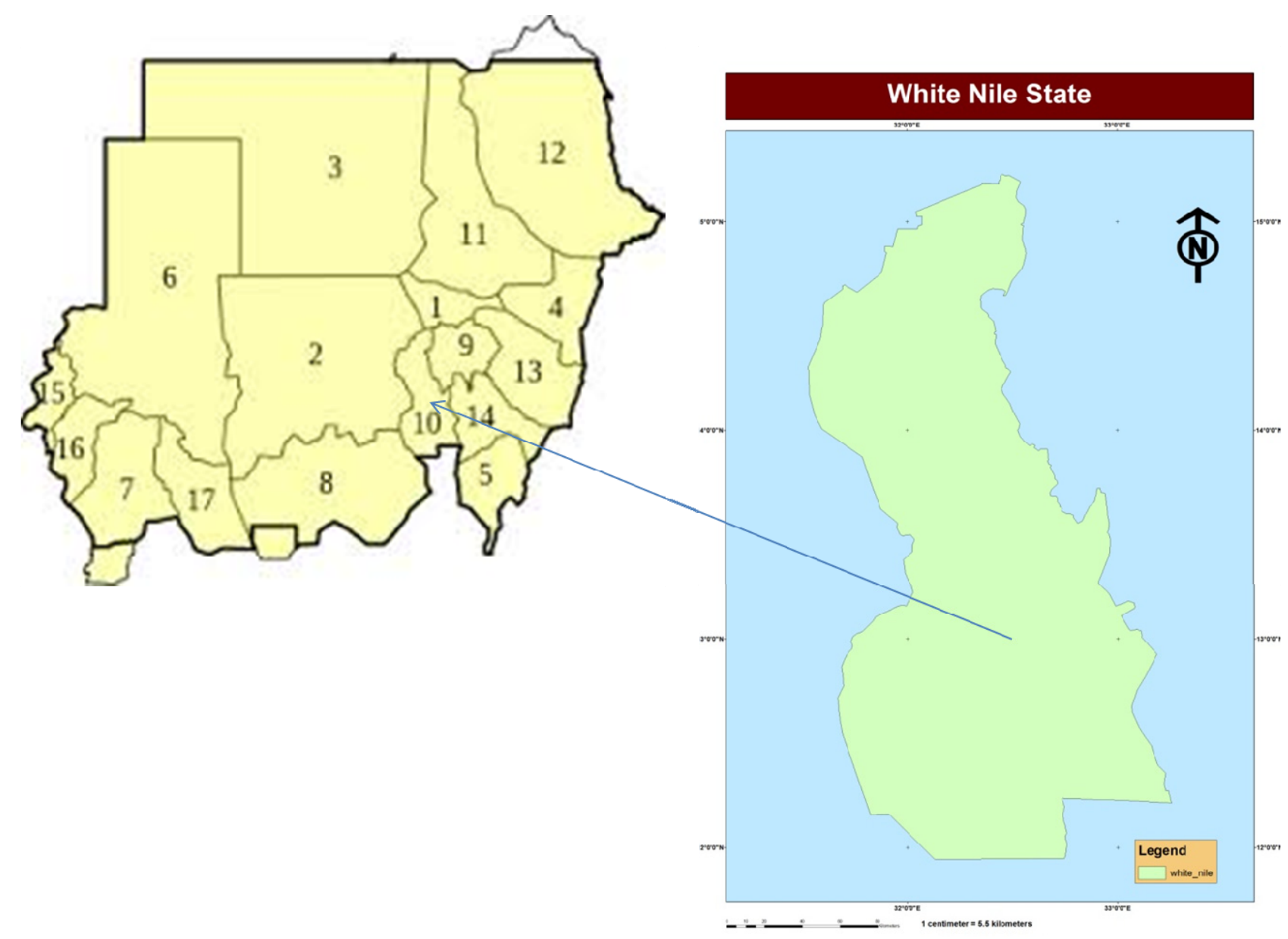

Plate 1 Study area: White Nile State.

Clausnitzer, V. and Martens, A. [2] carried out a study on dragonflies species from the Red Sea hills, the main Nile and Saharan part. White Nile Odonata has been surveyed since 1912. In particular areas like White Nile (south of Khartoum) in 1980 and Kostiin 1912, 1924, there is no new studies in this part of Sudan, although, White Nile area had many wetlands like water canals, khors and islands which is strong supportive to the diversity of Odonata.

In this study, the authors aimed to fill some gaps of Odonata distribution of this ecological interesting but poor region: White Nile state.

\section{Materials and Methods}

\subsection{Study Area}

This study was carried out in June 2014 at the beginning of the rainy season. Odonata surveys were

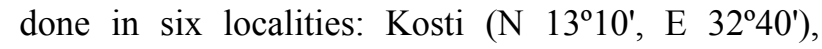
Al-Kawwa (N 1336.247', E 32³5.116'), ELJebelein (E 478,239.34 m, N 1,390,973.61), Kenana (E $\left.013^{\circ} 017.778^{\prime} \mathrm{m}, \mathrm{N} 032^{\circ} 52.534^{\prime}\right)$, Om Elganateer and El Shawat (E 12 $\left.21.733^{\prime}, \mathrm{N} 032^{\circ} 47.003^{\prime}\right)$ islands.

\subsection{Collection and Preservation}

Adult of dragonflies and damselflies were collected using butterfly nets, samples were preserved dry on envelopes.

\subsection{Identification}

Samples were checked under dissecting microscope and identified according to Dragonflies and Damselflies of South Africa guide [7]. Photos were taken by Sony Camera 14 megapixel and Nikon16 megapixel. 


\section{Results}

\subsection{Odonata Fuana}

A total of 16 species from five families: Lestidae, Coenagrionidae, Gomphidae, Macromiidae and Libellulidae, have been collected and 357 observed from six localities in White Nile state. Family Libellulidae was dominant with 9 species followed by family Coenagrionidae.

\section{Discussion}

A total of 16 species from 4 families were recorded and 357 individuals were observed in six localities in White Nile state (Plate 1). In the beginning of rainy season (June), the number of Eichhornia sp plants was increasing in the White Nile banks (Plate 2) where variety in species of dragonflies and damselflies had been observed. Urothemis edwardsii was recorded in some islands in ELJebelein like Om Elganateer and Algaya, and Kenana (Fig. 1) mainly in Lily Lakes (Plate 3). Brachythemis leucosticte was most recorded species followed by, pantala flavescens and Trithemis annulata almost found in all habitats. ELJebelein area showed highest number of Odonata because of the variety of Wetland areas (Plates 4 and 5), while Kenana showed highest diversity 11 species were recorded from Kenana sugar scheme and Kenana Zoo Park, and Olpogastra lugubris was recorded only in Kenana (Table 1). Agriocnemis exilis was recorded for first time in Sudan, and it had been recorded only once in northern Egypt in 1911-1912 and Port-Said, Martin in 1915 [8] and in the upper Nile system in southern.

Ictinogomphus ferox was reported as least concern in all Africa. In northeastern Africa, this species is widespread in tropical Africa and it needs more researches to confirm the status. Ictinogomphus ferox was considered native for Kenya and Uganda. There is no record in Egypt but it presents in Ethiopia, but probably only from a single record [9]. I. ferox was recorded for first time in Sudan on 1961 in Yambio which is now part of south Sudan, and the sample is preserved in National Museums of Kenya, Nairobi (Coryndon Museum) (Pinhey, 1961). In this study, 7 samples were observed in El Shawat, Om Elganateer and Al-Kawwa (Fig. 2).

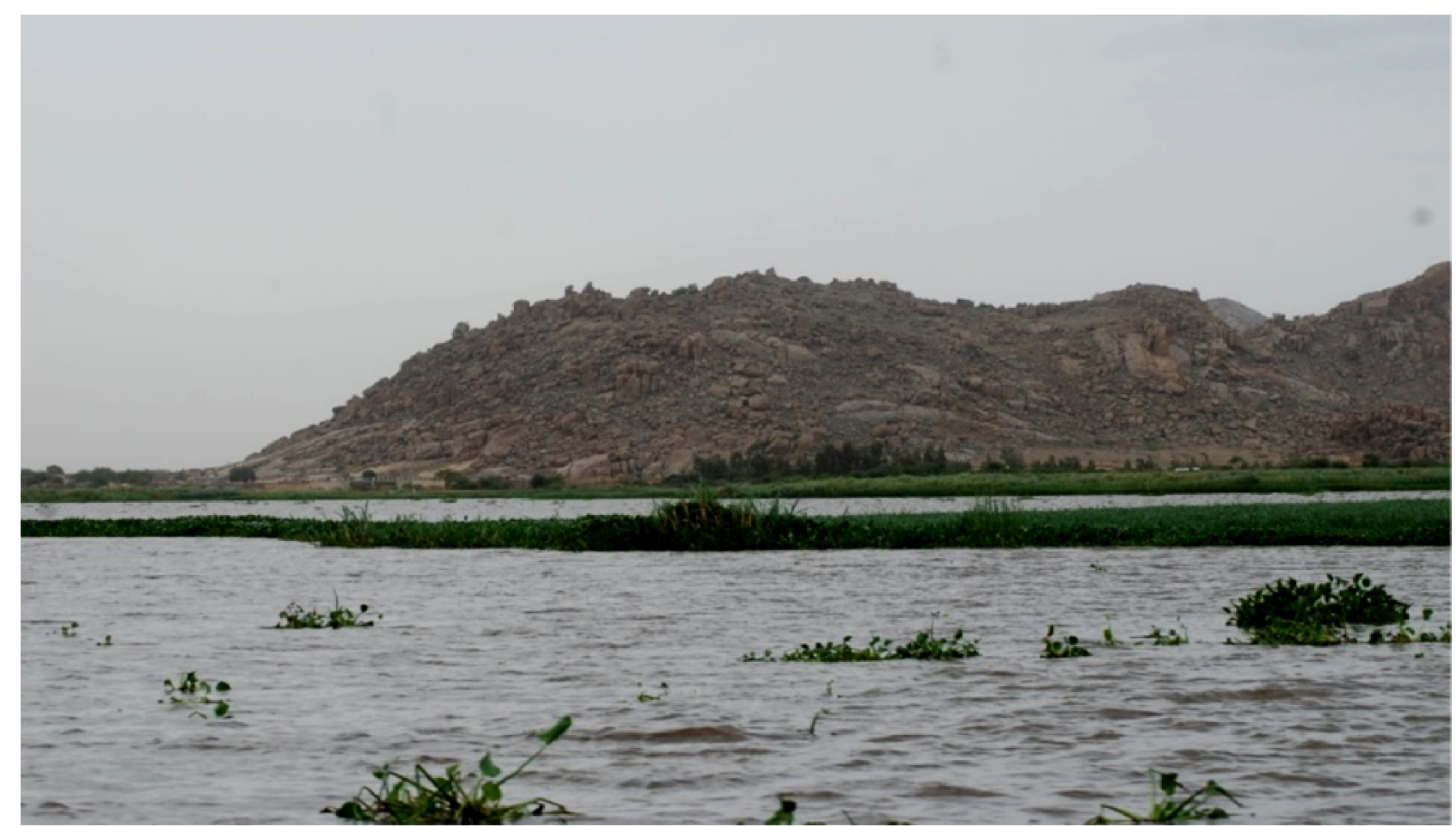

Plate 2 White Nile river. 


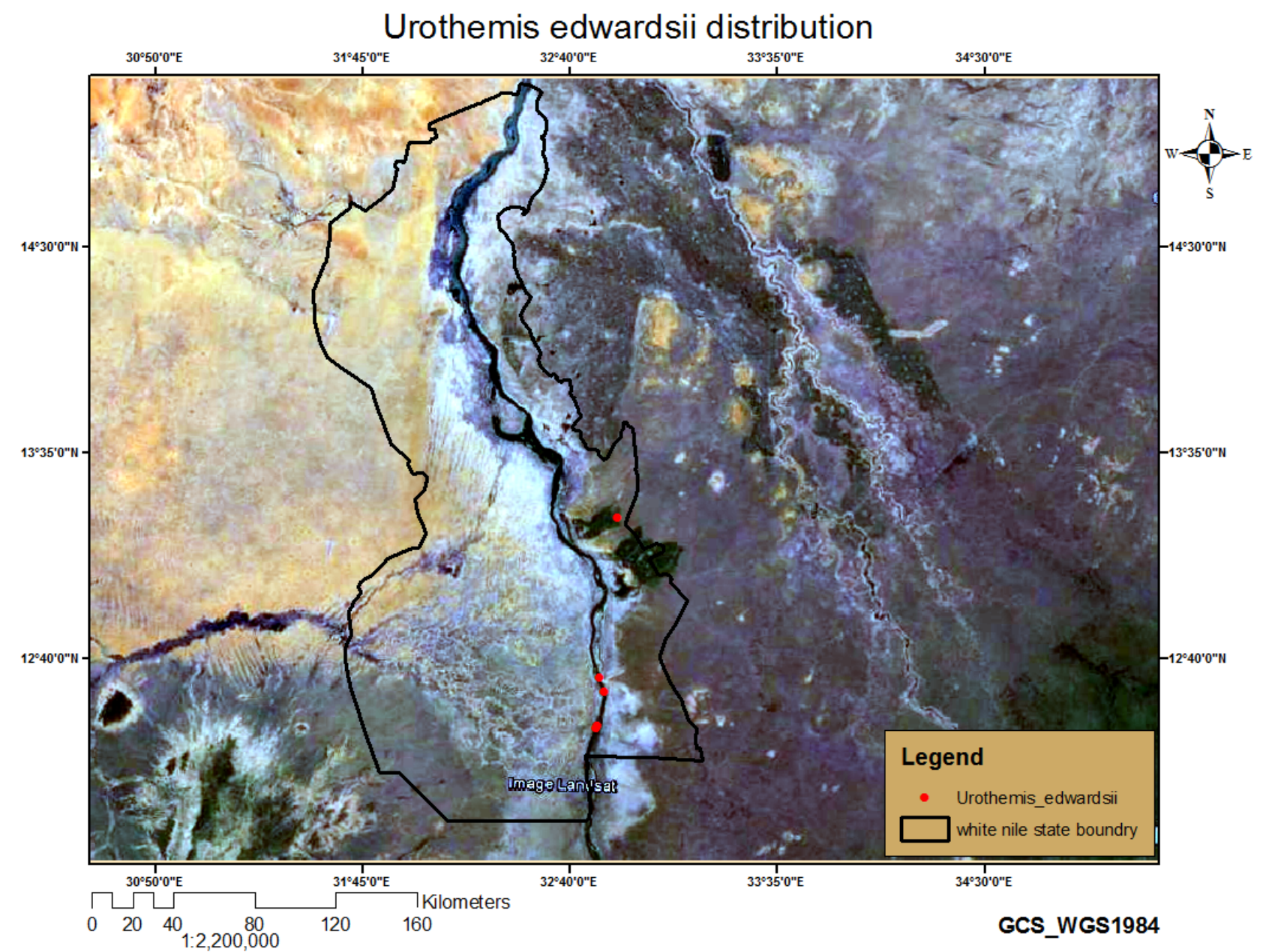

Fig. 1 Distribution map of Urothemis edwardsii (Selys) Blue Basker in White Nile state.

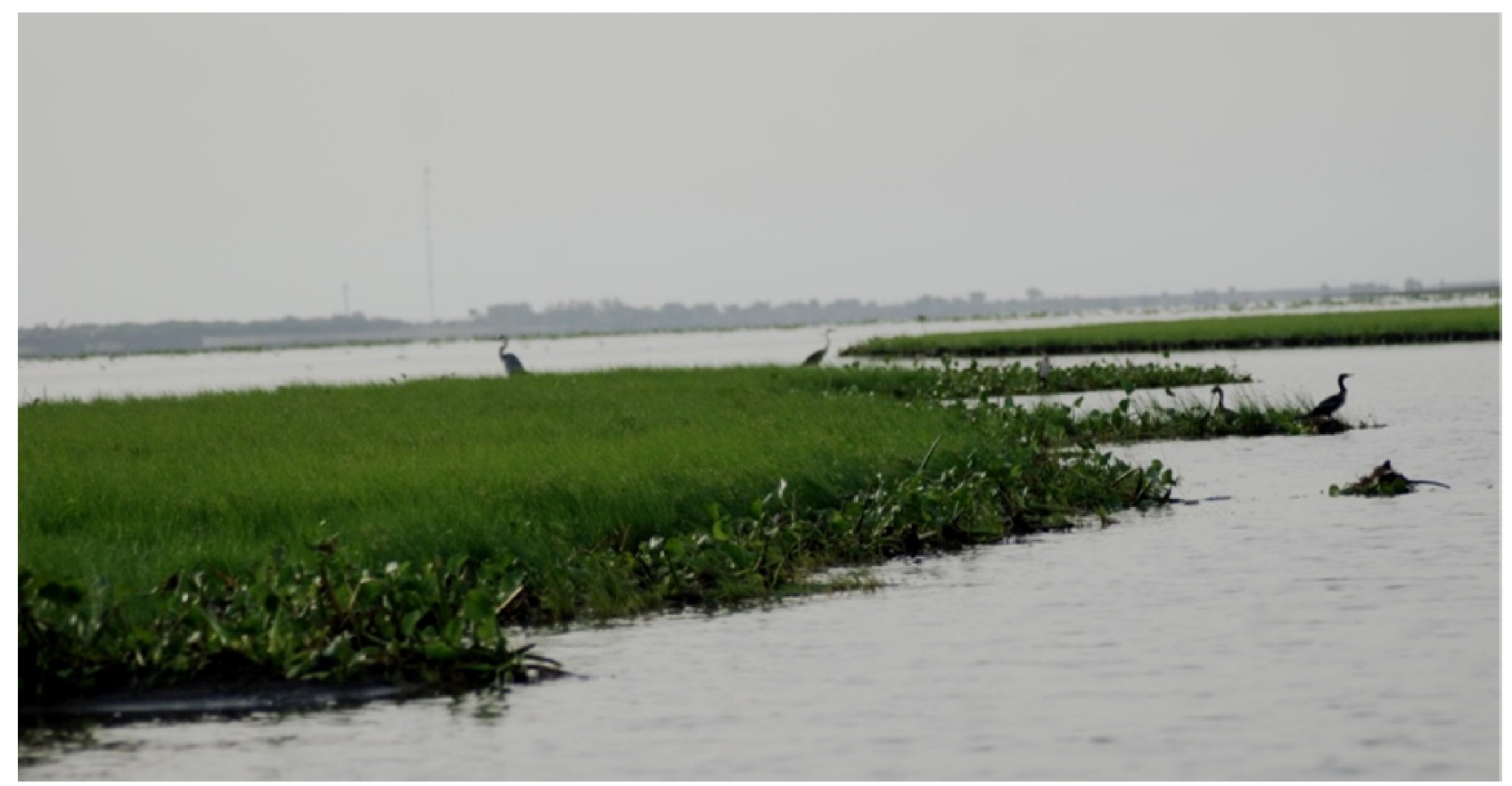

Plate 3 Lily Lake in Om Elganteer. 


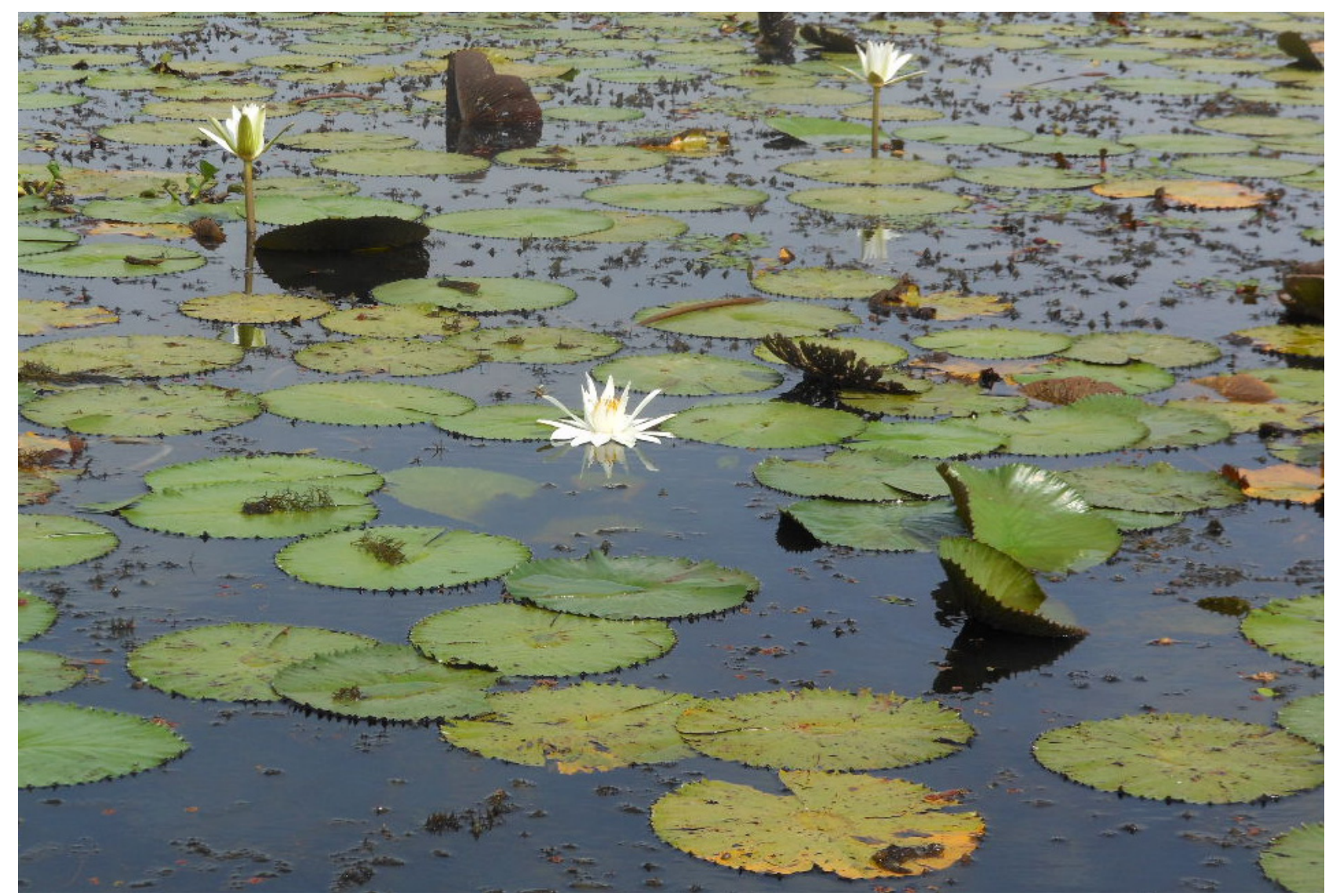

Plate 4 Separated islands.

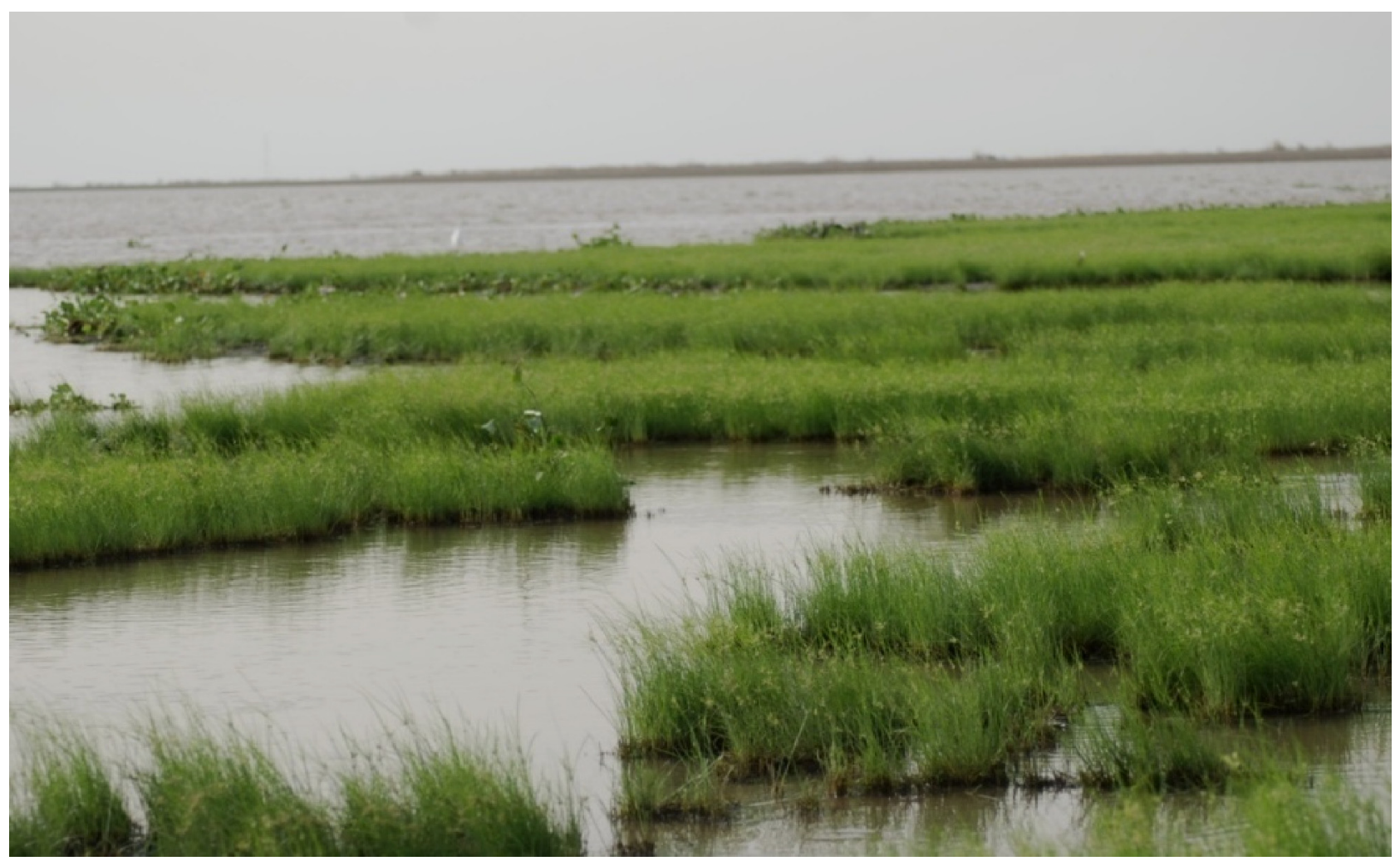

Plate 5 Wetland area in ELJebelein. 
Table 1 Odonata species in different localeties in White Nile.

\begin{tabular}{llllllll}
\hline Odonata sp & Kosti & Al-Kawwa & ELJebelein & Kenana & Om Elganateer & El Shawat & Total \\
\hline P. niloticum & 0 & 2 & 0 & 0 & 0 & 0 & 2 \\
P. torridum & 0 & 17 & 0 & 2 & 0 & 0 & 19 \\
Agriocnemis exilis & 0 & 0 & 0 & 0 & 0 & 6 & 6 \\
Ischnura senegalensis & 0 & 4 & 4 & 8 & 10 & 0 & 26 \\
Lestes pallidus & 0 & 1 & 0 & 0 & 0 & 0 & 1 \\
Brachythemis leucosticte & 14 & 30 & 30 & 12 & 10 & 10 & 106 \\
Trithemis annulata & 4 & 10 & 6 & 10 & 4 & 0 & 34 \\
Orthetrum Sabina & 0 & 5 & 6 & 0 & 0 & 0 & 11 \\
Ictinogomphus ferox & 0 & 1 & 0 & 0 & 4 & 2 & 7 \\
Terma basilaris & 0 & 1 & 0 & 0 & 0 & 0 & 1 \\
Urothemis edwardsii & 0 & 0 & 6 & 4 & 4 & 0 & 14 \\
Crocothemis eythraea & 0 & 0 & 2 & 2 & 2 & 0 & 6 \\
Pantala flavescens & 22 & 0 & 55 & 20 & 0 & 0 & 97 \\
Diplacodes lefebvrii & 0 & 0 & 2 & 2 & 6 & 2 & 12 \\
Olpogastra lugubris & 0 & 0 & 0 & 1 & 0 & 0 & 1 \\
Phyllomacromia Africana & 0 & 0 & 0 & 14 & 0 & 0 & 14 \\
Total & 40 & 71 & 111 & 75 & 40 & 20 & 357 \\
\hline
\end{tabular}

Table 2 The conservation status according to the IUCN (International Union for Conservation of Nature) Red list.

\begin{tabular}{llll}
\hline Odonata sp & IUCN Red list status & Observations in this study & Red list publishing year \\
\hline Pseudagrion niloticum (Dumont, 1978) & Least Concern LC & Rare & 2016 \\
Pseudagrion torridum (Selys, 1876) & Least Concern LC & Common & 2016 \\
Agriocnemis exilis & Least Concern LC & (First record in Sudan) & 2016 \\
Ischnura senegalensis (Rambur, 1842) & Least Concern LC & Common & 2016 \\
Lestes pallidus (Rambur, 1842) & Least Concern LC & Rare & 2016 \\
Brachythemis leucosticte (Burmeister, 1839) & Least Concern LC & Common & 2016 \\
Ictinogomphus ferox (Rambur, 1842) & Least Concern LC & (First record in Sudan) & 2016 \\
Trithemis annulata (Palisot de Beauvois, 1807) & Least Concern LC & Common & 2016 \\
Crocothemis eythraea (Brullé, 1832) & Least Concern LC & Common & 2016 \\
Orthetrum Sabina (Drury, 1773) & Least Concern LC & Common & 2013 \\
Terma basilaris (Palisot de Beauvois, 1807) & Least Concern LC & Rare & 2016 \\
Pantala flavescens (Fabricius, 1798) & Least Concern LC & Common & 2016 \\
Diplacodes lefebvrii (Rambur, 1842) & Least Concern LC & Common & 2016 \\
Olpogastra lugubris (Karsch, 1895) & Least Concern LC & Rare & 2016 \\
Phyllomacromia africana (Schouteden, 1934) & Least Concern LC & common & 2010 \\
Urothemis edwardsii (Selys, 1849) & Least Concern LC & Common & 2016 \\
\hline
\end{tabular}

Pantala flavescens is one of the most recorded species in tropical Africa and considered Vagrant species in Sudan. In White Nile state, it has been seen only inside the cities (Kosti and ELJebelein) (Table 1), flying in groups above temporary rainwater lakes. $P$. niloticum is rarely seen one pair observed in Al-Kawwa, and reported as Least Concern (Table 2), for North Africa region according to IUCN North Africa Red list
(2016) [10]. Phyllomacromia africana is observed fling in group, and recorded only in Kenana. This species is known from Uganda to Sudan, possibly Egypt, Ghana and Senegal [9].

The presence of this species in different habitats in White Nile state underlies the important of this habitat in Odonata conservation of Sudan, fresh water lakes, ponds and water canals which all support Odonata population. 


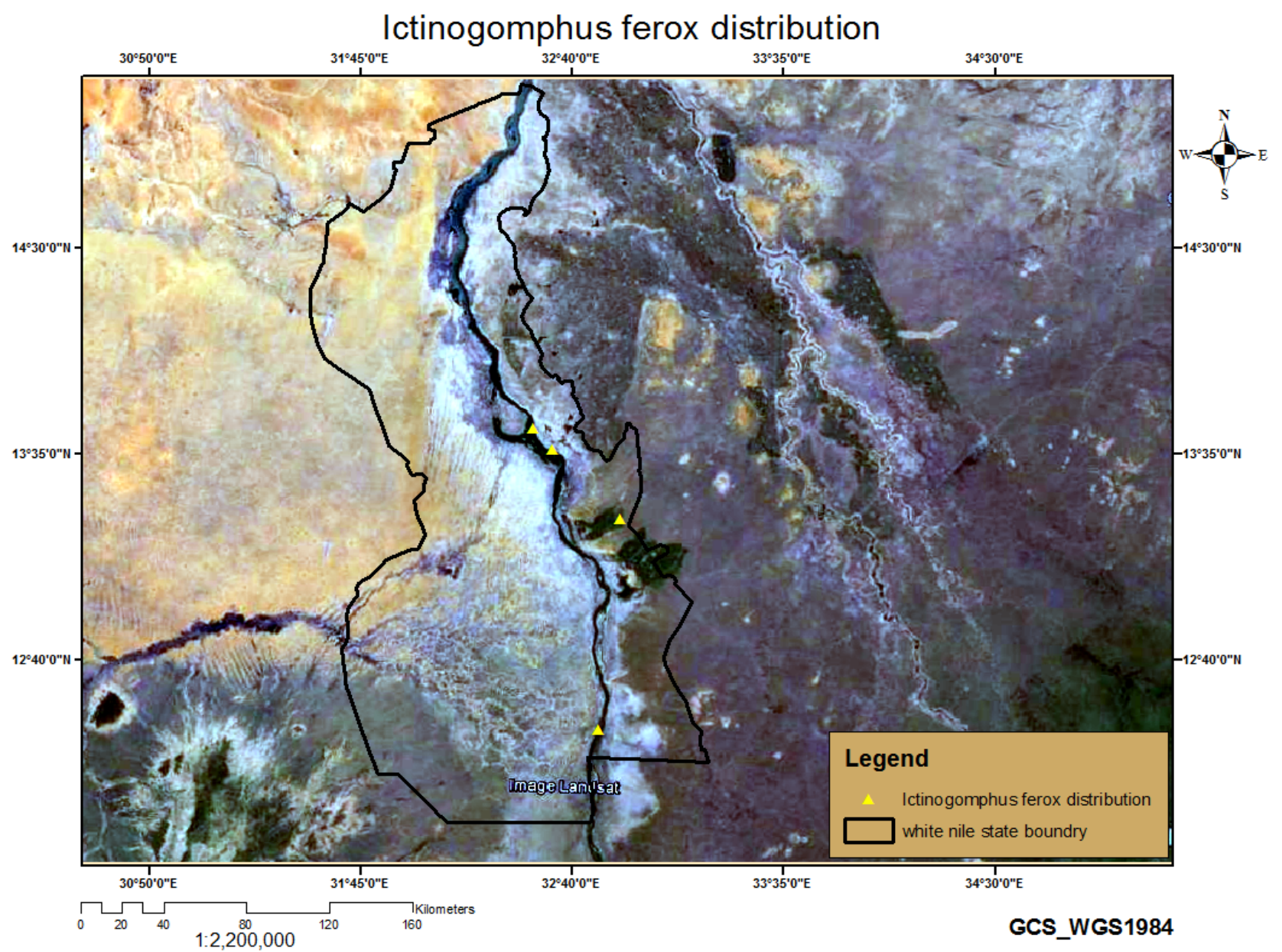

Fig. 2 Distribution of Ictinogomphus ferox (Rambur, 1842), recorded in Yambio (southern Sudan) in 1961. There is no recent record in north Sudan.

There is no recent research mainly on conservation status of Odonata of Sudan. Some species like Paragomphus sinaiticus, is reported as Vulnerable for all north Africa region [11]. In this study, all observed species are reported and as Least Concern according to Red list report and (Table 2), it is considered widespread species and does not need any protection actions.

\section{Conclusions}

More researches need to be done in Odonata of Sudan especially areas that receive low importance in research.

\section{References}

[1] UNDP. 2010. Assessment Report for White Nile State
Joint Mission (NSDDRC-SC/UNDP) Socio-economic and Opportunity Mapping 26th-28th October 2010. Accessment report.

[2] Clausnitzer, V., and Martens, A. 2004. "Critical Species of Odonata in the Comoros, Seychelles, Mascarenes and Other Small Western Indian Ocean Islands." International Journal of Odonatology 7 (2): 207-18.

[3] Ris, F. 1914. "Scientific Results of the Zoological Expedition to the Anglo-Egyptian Sudan (Kordofan) Undertaken by the Academy of Sciences in Vienna from the Treitl Legacy." Memorandum of the Academy of Sciences, Vienna, Mathematical-natural Science Class 99: 275-82.

[4] Happold, D. C. D. 1968. "Seasonal Distribution of Adult Dragonflies at Khartoum, Sudan." Rev. Zool. Bot. Afr. 77: 50-61.

[5] El Rayah, E. A., and Abu-Shama, F. T. 1977. "Predatory Capacity of Nymphs of the Dragonflies: Trithemis Annulata Scortecii Nielsen (Odonata: Anisoptera) and Ischnura Senegalensis Rambur (Odonata: Zygoptera)." 
Revue de Zoologie Africaine.

[6] Dumont, H. J., and Martens, K. 1984. "Dragonflies (Insecta, Odonata) from the Red Sea Hills and the Main Nile in Sudan." Hydrobiologia 110 (1): 181-90.

[7] Samways, M. J. 2008. Dragonflies and Damselflies of South Africa. Pensoft Publishers, Bulgaria.

[8] Clausnitzer, V., Boudot, J. P., Dijkstra, K. D. B., and Suhling, F. 2016. "Agriocnemis Exilis." The IUCN Red List of Threatened Species 2016. Accessed February 3, 2017. http://dx.doi.org/10.2305/IUCN.UK.2016-3. RLTS.T59800A75331140.en.

[9] Clausnitzer, V., Suhling, F., and Dijkstra, K. D. B. 2016.
"Ictinogomphus ferox." The IUCN Red List of Threatened Species 2016. Accessed February 3, 2017. http://dx.doi.org/10.2305/IUCN.UK.2016-3.RLTS.T5989 4A85585956.en.

[10] Clausnitzer, V. 2016. The IUCN Red List of Threatened Species 2016. Accessed February 3, 2017. http://dx.doi.org/10.2305/IUCN.UK.2016-3.RLTS.T5980 0A75331140.en.

[11] Garcia, N., Cuttelod, A., and Malak, D. A. 2010. The Status and Distribution of Freshwater Biodiversity in Northern Africa. Gland, Switzerland, Cambridge, UK, and Malaga, Spain: IUCN. 